\title{
Artelogie
}

Recherche sur les arts, le patrimoine et la littérature de l'Amérique latine

10 | 2017

Après le paysage : l'art, l'inscription et la représentation de la nature en Amérique latine aujourd'hui

\section{Ante los paisajes de hielo. Reseña a la exposición "Hidropoética, expediciones Antárticas", curaduría de Ricardo Mancillas Garay}

Museo de Arte Contemporáneo de Santiago, 2017

\section{María Teresa Márquez}

\section{OpenEdition}

\section{Journals}

\section{Edición electrónica}

URL: http://journals.openedition.org/artelogie/883

DOI: 10.4000/artelogie. 883

ISSN: 2115-6395

Editor

Association ESCAL

Referencia electrónica

María Teresa Márquez, «Ante los paisajes de hielo. Reseña a la exposición "Hidropoética, expediciones Antárticas", curaduría de Ricardo Mancillas Garay », Artelogie [En línea], 10 | 2017, Publicado el 05 abril 2017, consultado el 23 septiembre 2020. URL : http://journals.openedition.org/ artelogie/883 ; DOI : https://doi.org/10.4000/artelogie.883

Este documento fue generado automáticamente el 23 septiembre 2020

Association ESCAL 


\section{Ante los paisajes de hielo. Reseña a la exposición "Hidropoética, expediciones Antárticas", curaduría de Ricardo Mancillas Garay}

Museo de Arte Contemporáneo de Santiago, 2017

María Teresa Márquez

Entre 1557 y 1559, el navegante español Juan Ladrillero realiza una expedición que tiene por objetivo hallar un acceso occidental al Estrecho de Magallanes. En este viaje, se topa con un gran entrante de mar (un seno) que confunde con su propósito. Algo desanimado, Ladrillero percibe en lo acontecido su última esperanza de hallar el Estrecho de Magallanes, por esto decide bautizar el seno con el nombre de Última Esperanza. El español comenzó su expedición por mandato del Virrey del Perú, Andrés Hurtado de Mendoza, ya que, en ese entonces, para la corona española dominar el estrecho significaba monopolizar el paso entre los océanos. Un par de siglos después de la excursión de Juan Ladrillero, en el año 2004, los artistas chilenos Sandra Ulloa y Nataniel Álvarez forman, en territorio Subantártico (Punta Arenas-Puerto Natales), un colectivo de arte experimental llamado Última Esperanza.

El conjunto de artistas ha trabajado temáticas ligadas a la identidad, al territorio y al paisaje, dándole un papel importante al uso de medios tecnológicos -como el video y la proyección- en el desarrollo de sus obras, las cuales han sido expuestas en Chile, Argentina, Uruguay, México, EE.UU., España y Alemania. Uno de los trabajos que han desarrollado recientemente es Hidropoética, proyecto que los ha llevado a explorar el continente antártico, con el objetivo de crear obras que propician la reflexión en torno a una zona geográfica que, en varias oportunidades, se ha visto envuelta en conflictos de soberanía. De ahí nace la exposición "Hidropoética, expediciones Antárticas", una muestra que, a partir de las obras Seis sujetos, Poéticas para una ficción y Terra australis incógnita, nos invita a conocer las diversas construcciones que pueden surgir a partir de un mismo lugar, donde se contrastan el afán estatal por apropiarse de un territorio y 
las ficciones que habitantes cercanos a la Antártica son capaces de crear en relación a esta zona geográfica.

3 El verano en Santiago trae temperaturas que, muchas veces, superan los 30 grados. El calor deja en claro que cada año será más intenso y prolongado. El clima está en crisis y nace la necesidad de adaptarnos y aceptar que los paisajes que hoy observamos, en un tiempo más, no serán más que recuerdos. Frente a este escenario, el Museo de Arte Contemporáneo, de muros gruesos y arquitectura neoclásica, ofrece un frescor necesario en los insoportables días que llegan y parecen no irse nunca. En este contexto, en una sala del segundo piso, nos encontramos con Seis sujetos, obra que reproduce en una serie de pantallas, las entrevistas realizadas a personas de Punta Arenas, quienes narran lo que para ellas significa el territorio Antártico. Los videos no solo dan a conocer las construcciones que cada sujeto hace en relación al lugar, sino que funcionan como los registros de un acto poético llevado a cabo por los artistas, pues las pantallas lo que realmente retratan es el ejercicio de transportar estas ficciones al lugar real. Al proyectar la imagen del entrevistado directamente en los hielos antárticos, el colectivo de artistas superpone las imágenes mentales de estas personas, sus relatos ficcionales, en la superficie material del continente más austral de la tierra.

Colectivo Última Esperanza, Seis sujetos, Instalación, 2016

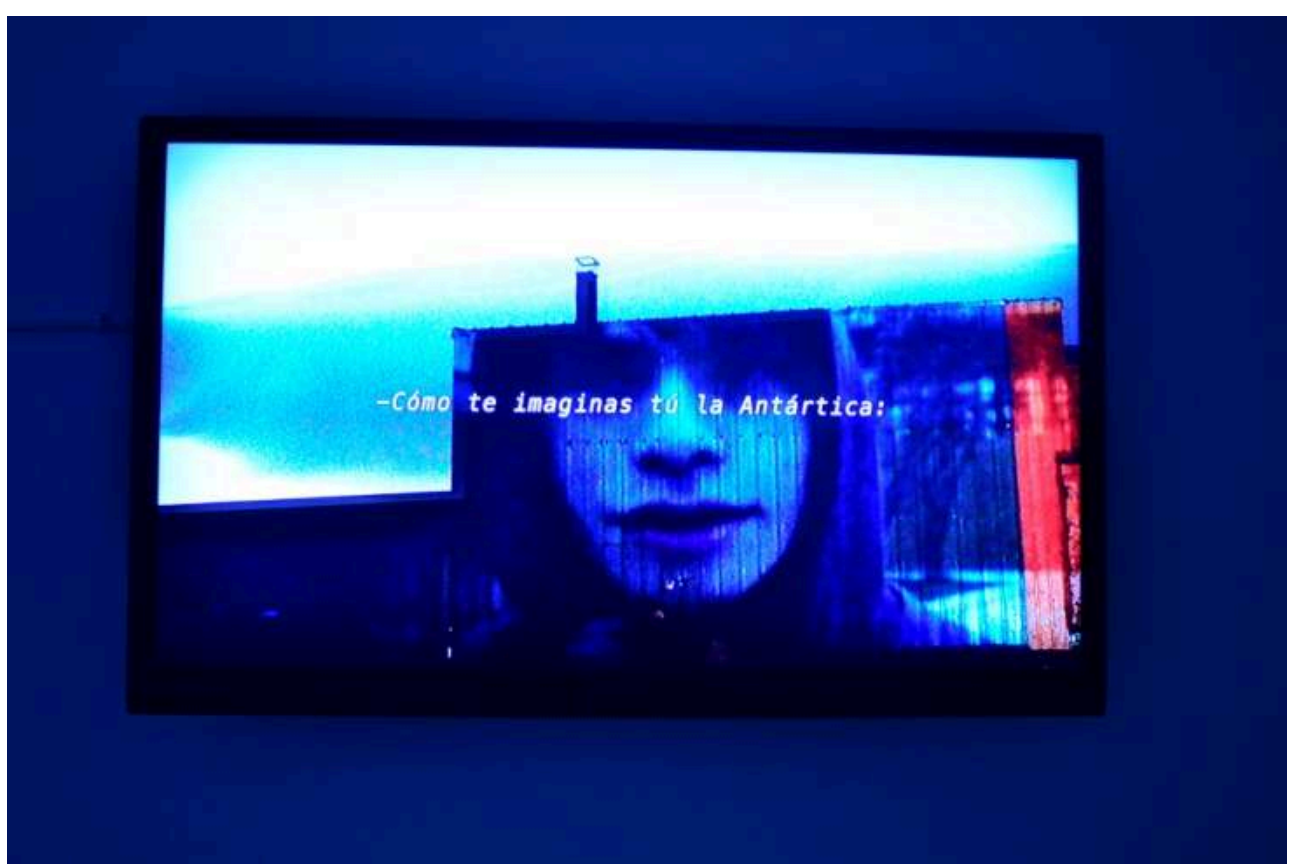

(c) Marissa Olivia Niño, cortesía de PAM (Plataforma de Arte y Medios)

4 Separada por un muro, a un par de metros de Seis Sujetos, se exhibe Poéticas para una ficción, trabajo que contrasta el interés político por el territorio con la búsqueda de una cierta identidad de los que habitan en las cercanías de la denominada Antártica chilena. Aquí vemos cómo la proyección de un discurso del expresidente chileno Gabriel González Videla -el primero en su cargo en visitar la Antártica, en 1948- se enfrenta a la proyección de dibujos del territorio, hechos por estos pobladores que no conocen directamente el lugar que retratan. Mientras que González Videla busca asegurar la 
soberanía territorial, las personas se apropian del territorio al intentar encontrarse con él a través de la imagen que construyen y llevan al papel.

Colectivo Última Esperanza, Poéticas para una ficción, Instalación, 2016

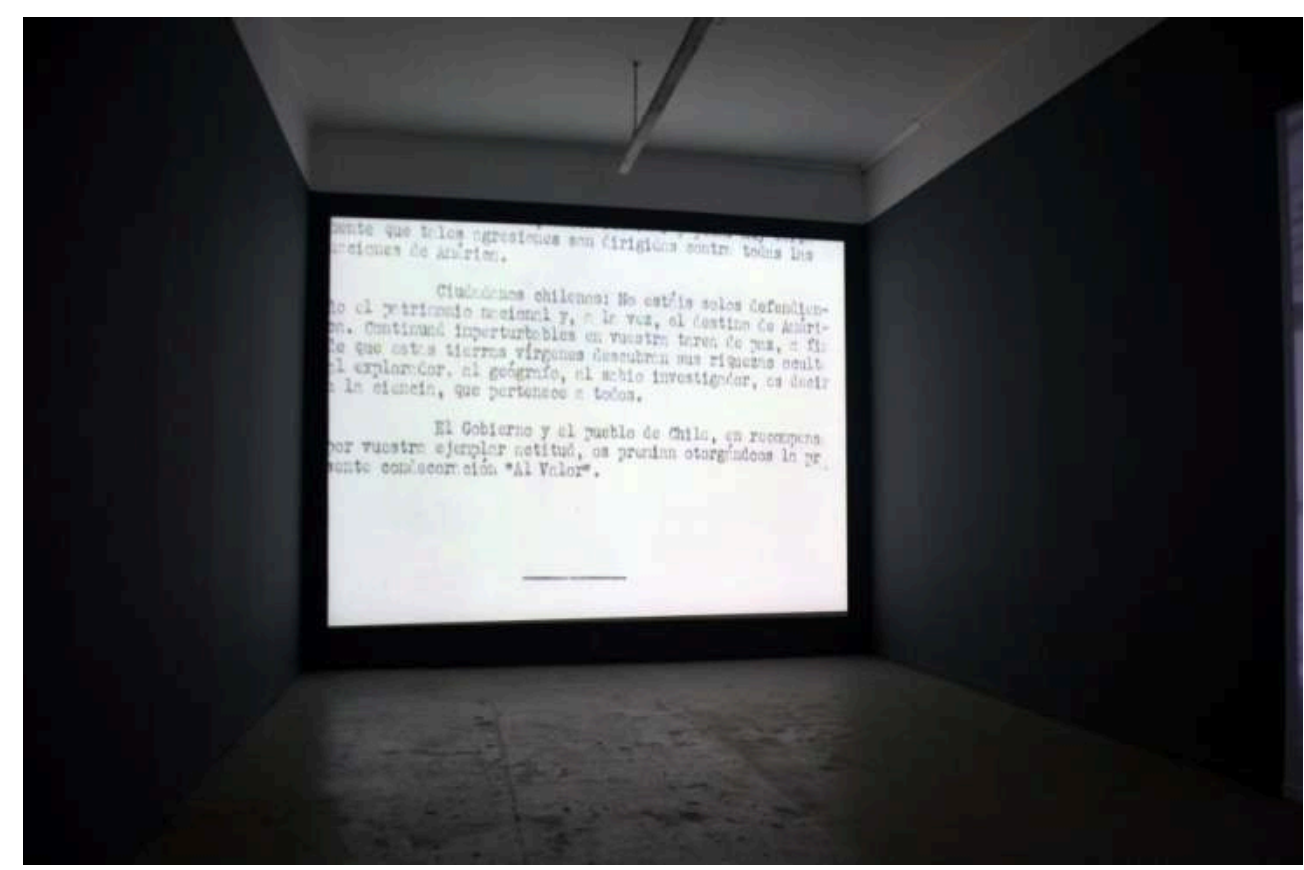

(c) Marissa Olivia Niño, cortesía de PAM (Plataforma de Arte y Medios)

5 Finalmente, a un costado de ambas obras, en una tercera sala, se encuentra Terra Australis incógnita, una instalación sonora compuesta por tres elementos: un gran dibujo de la antártica chilena hecho en suelo (una silueta similar a la que podemos encontrar en un mapa), altavoces que reproducen las mismas entrevistas de la obra Seis sujetos y, en el centro de uno de los muros, la pregunta “ ¿En quiénes nos convertimos frente a los paisajes del hielo?". La obra nos interpela directamente, ya no somos solo testigos de las subjetividades que giran en torno a las representaciones del territorio, ahora somos nosotros quienes debemos responder y construir una ficción, pero no del lugar, sino de nosotros mismos. De la posición que tomamos, como habitantes del resto del planeta, al imaginar cómo son, precisamente, los paisajes de la Antártica. 


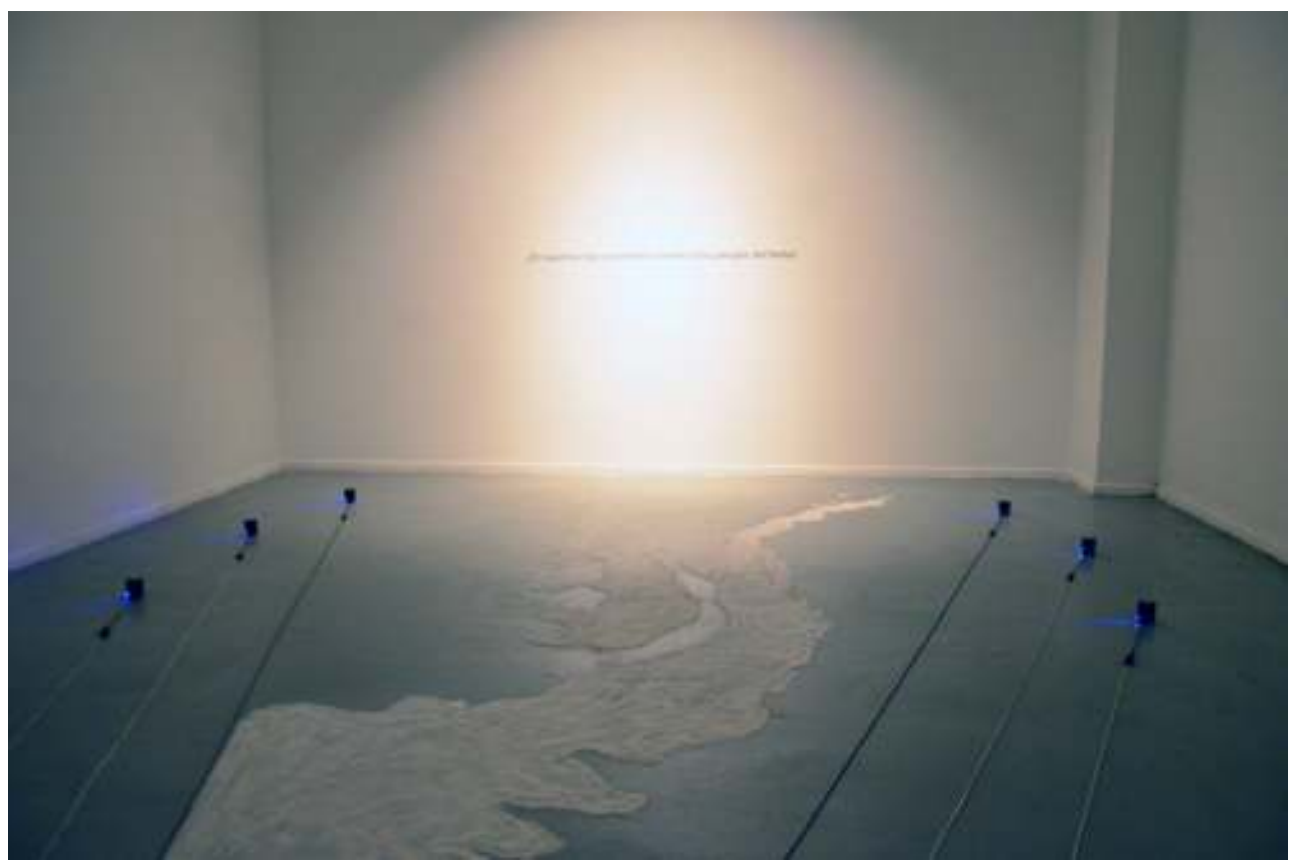

(c) Marissa Olivia Niño, cortesía de PAM (Plataforma de Arte y Medios)

Pensar un territorio es un gesto básico para la constitución de un paisaje, es el comienzo de cualquier representación de la naturaleza. En "Hidropoética, expediciones Antárticas", este ejercicio es recurrente y colectivo, por lo que los resultados son variados. Por una parte, tenemos las imágenes que las pantallas y proyectores nos presentan, pero, por otra, también están los paisajes que no se ven, los construidos en la imaginación de los habitantes, así como en las nuestras. Las obras dejan entrever además otro tipo de imágenes de carácter igualmente subjetivo, pero de tono oficial, son aquellas representaciones elaboradas por intereses políticos y económicos que demarcan con líneas imaginarias los límites de cualquier lugar.

7 En cualquiera de los casos, pensando en la inminente transformación de los territorios a causa de los cambios que rápidamente está aconteciendo en el planeta, estas múltiples imágenes congelan paisajes de hielo que, con algo de nostalgia, advierten su pronto desvanecimiento.

\section{AUTOR}

\section{MARÍA TERESA MÁRQUEZ}

Estudiante Pedagogía en Arte, Universidad Alberto Hurtado

Markz.maria[at]gmail.com 